\title{
Some Observations of Protoplasmic Streaming in Acetabularia*
}

\author{
by Noburô KAMIYA** and Kiyoko KURODA**
}

Received August 27, 1966

\section{Introduction}

Acetabularia, a coenocytic green marine alga, is one of the beautiful materials exhibiting cytoplasmic streaming of the so-called "multistriate" type"). In the stalk of this alga before the fertile rays (cap) develop, characteristic protoplasmic streaming takes place in the form of many slender channels along fibrous gel structure, or striations, running longitudinally inside the thin ectoplasmic layer. The flow of cytoplasm along each striation occurs either in acropetal or basipetal direction carrying many chloroplasts in trains, where channels of oppositely directed streams do not necessarily alternate from one channel to the adjacent one. Although there are some branchings connecting one streaming channel with the next, it is generally the case that each stream is more or less separated from one another with zones of unequal widths where cytoplasm is quiescent. Thus we see many parallel streams of cytoplasm and chloroplasts going simultaneously in opposite directions in one and the same stalk.

The total number of streams in a stalk is indefinite according to individual specimens, but usually it is found in the range of 50-100, of which the numbers of acropetal and basipetal streams are approximately the same under normal conditions.

Although there have been some interesting experiments performed already on the streaming in Acetabularia, ${ }^{2,3)}$, our knowledge about basic characteristics of the multistriate streaming is still meager. It is the purpose of the present paper to throw some light on hitherto unknown physical properties of the streaming, properties which might help understand the mechanism of multistriate streaming. Our effort has been devoted to observations of the behavior of protoplasm when it was pushed aside in a living cell through application of centrifugal force as well as when it was isolated in vitro.

\section{Experimental}

Acetabularia calyculus, which was collected in the Inland Sea near the Tamano Marine Biological Station of Okayama University, served as the exclusive material in the present work. The material has been kept in the laboratory in the filtered natural sea water under fluorescent light at $23^{\circ}$ before it was used for the experiment. The experiments were performed within 3 weeks after the material was collected. Throughout this period, the alga behaved quite normally as far as the streaming is concerned. For observation the young alga, about $1-3 \mathrm{~cm}$ long, was first ligated with a strip of silk thread near the base which is firmly attached to the

* Supported by Grants-in-Aid from the Ministry of Education and by a Research Grant from the Takeda Foundation for the Promotion of Sciences.

** Department of Biology, Faculty of Science, Osaka University, Toyonaka, Osaka, Japan. 
shell by rhizoids. The stalk was then freed from the shell and rhizoids by cutting the alga beyond the ligature. Since the single huge nucleus is still in a rhizoid at this stage, the detached stalk is anuclear. But cytoplasmic streaming in an anuclear, freed stalk lasts normally a week or longer.

Since the endoplasm involved in streaming is nearly transparent containing few visible particles other than chloroplasts, the latter was used as an index marker of cytoplasmic motility. The normal rate of chloroplasts' streaming in the young alga we used is rather moderate with a maximum of $2 \mu / \mathrm{sec}$, but it fluctuates from one channel of flow to another. For observing and recording the movement, we took advantage of the time lapse technique of ciné-micrography.

For observation while the material is being centrifuged was used a Harvey-type centrifuge-microscope manufactured by Struers (Copenhagen, Denmark). The speed of rotation was determined stroboscopically with intermittent light, the period of which is under control. The centrifugal force was applied either longitudinally or laterally to the stalk.

For isolating the naked cytoplasm from the stalk, the stalk was cut with sharp scissors and the cell contents were squeezed out into liquid paraffin so that the cy 50 plasmic drops containing many chloroplasts are suspended in the natural cell sap surrounded by the liquid paraffin. Motility of the cytoplasm thus isolated in vitro lasts at least a few days.

\section{Centrifugation}

Behavior of the cytoplasm while the cell is centrifuged as well as the process of restitution of the dislocated cell contents after centrifugation gives us an instructive information about physical characteristics of the streaming in the material. For centrifuge-microscope observation the stalk was introduced into an observation chamber constructed suitably according as the material was placed radially or tangentially to the centrifuge rotation.

a) Centrifugation in the longitudinal direction. When the cell is centrifuged longitudinally at about $1200 \mathrm{~g}$, the chloroplasts and most of the endoplasm involved in streaming are shifted toward the centrifugal end of the cell. With the onset of centrifugation, some chloroplasts start sliding along the cell wall, but not a few chloroplasts are soon thrown out into the vacuolar space, connected with one another in trains with the cytoplasmic strands. These strands, once detached from the main mass of the cytoplasm on the cortex, fall down rapidly through the central vacuole onto the centrifugal end of the cell. There is no difference in behavior of protoplasm whether the stalk is centrifuged basipetally or acropetally. In 5 minutes most of the endoplasm and chloroplasts are collected at the centrifugal end, either apical or basal.

What is left behind after centrifugation are many gel striations running in parallel with unequal intervals underneath the cell wall. Though these striations are colorless and very thin right after centrifugation, their presence is confirmable by means of dark field or phase contrast optics (Fig. 1). If the living stalk is subjected to a centrifugal acceleration of $1500 \mathrm{~g}$ for 10 minutes or less, the thin cytoplasmic gel layer lining the cell wall, or ectoplasm, comes off from the cell with concomitant disappearance of the striations. This is a good evidence showing that the striation in question has nothing to do with the structuer of the cell wall but represeuts 


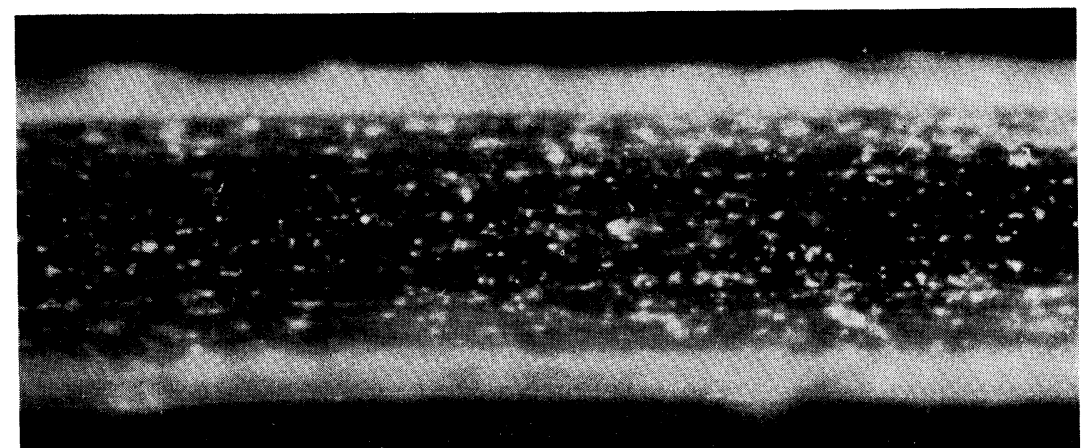

Fig. 1. A part of the stalk of Acetabularia calyculus after most of chloroplasts and endoplasm have been pushed aside through centrifugation to one end of the cell leaving parallel striations behind on the cortical layer. Taken $55 \mathrm{~min}$. after centrifugation at ca. $1200 \mathrm{~g}$ for $5 \mathrm{~min}$. Width of the stalk : $180 \mu$ (Dark field illumination).
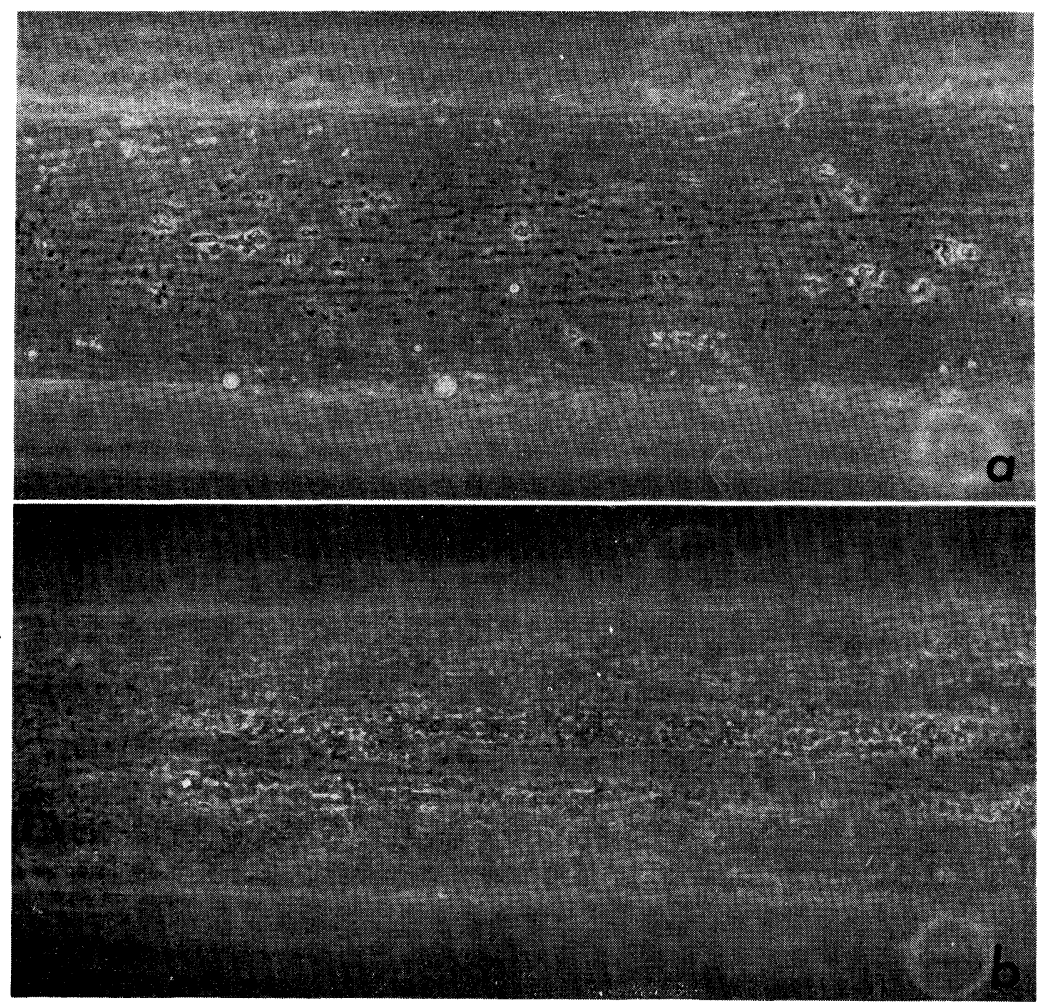

Fig. 2a. A part of the stalk from where chloroplasts and endoplasm are nearly evacuated through centrifugation at ca. $1200 \mathrm{~g}$ for $4 \mathrm{~min}$. in the longitudinal direction. Taken 6 min. after centrifugation. Width of the stalk: 180 $\mu$ (Dark phase contrast).

Fig. 2b. The same part of the stalk 90 min. after centrifugation, 
fibrous differentiation of the cytoplasm on the ectoplasm.

The endoplasm and the chloroplasts collected at one end of the cell start coming back as soon as centrifugation is stopped. At first very thin striations on the cortex become thicker, coated with the endoplasmic sol flowing back along them. In the meantime, chloroplasts packed at the centrifugal end tend to be moved as a coherent mass, but gradually they are carried by the streams of the endoplasm along the striations remaining on the cortex. In areas between two adjacent striations no restitutional streaming is observable. Fig. 2a shows striations remaining on the cortex 6 minutes after the cell was centrifuged with an acceleration of $1200 \mathrm{~g}$ for 4 minutes. Fig. $2 \mathrm{~b}$ shows restitution of the chloroplasts 90 minutes after centrifugation was stopped.

The fact that the plasmasol and the chloroplasts move back toward the centripetal end of the stalk only along the striations on the cortex shows their functional importance in the streaming mechanism of protoplasm.

b) Centrifugation in the lateral direction. When the stalk was centrifuged laterally, or at right angle to the longitudinal axis, at the same acceleration (about $1200 \mathrm{~g}$ ) for 5 minutes, most of the chloroplasts and endoplasm are pushed aside onto one side of the cylindrical stalk over its entire length (Fig. 3a). The situation is similar in this case to the foregoing one as far as delicate gel striations remain attached to the cortex.

Direct observation of the streaming while the alga is being centrifuged laterally reveals even more clearly than when it is centrifuged longitudinally that channels of streaming are moved as unit strands of cytoplasm loaded with trains of chloroplasts. Centrifugal acceleration of $1200 \mathrm{~g}$ is strong enough to "derail" forcefully these
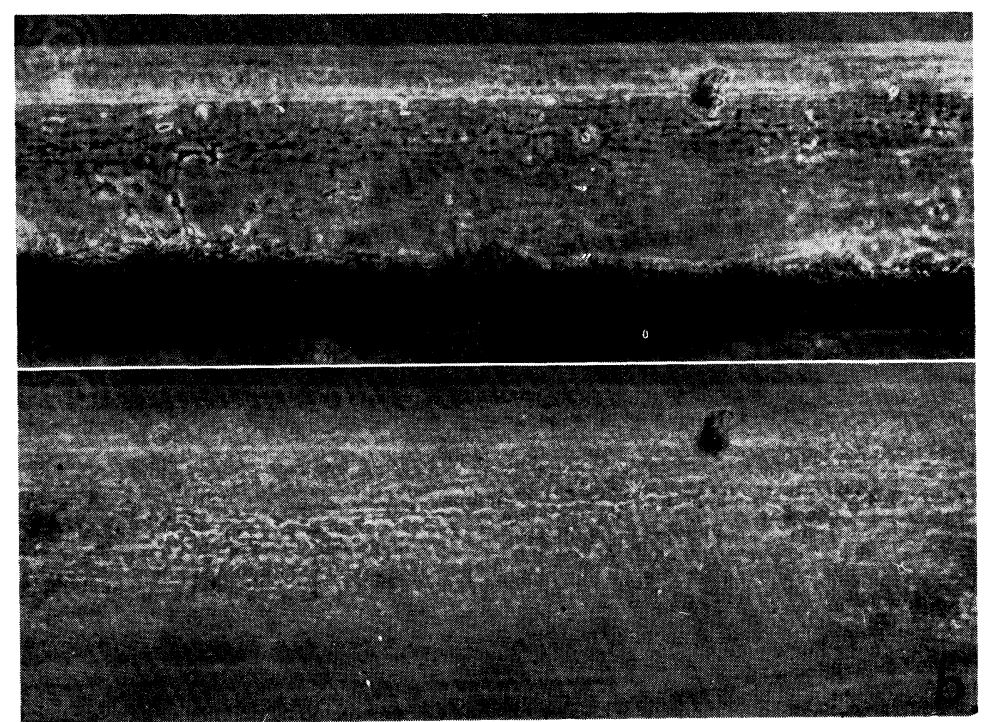

Fig. 3a. The stalk of Acetabularia $3 \mathrm{~min}$. after centrifugation at ca. $1200 \mathrm{~g}$ for $5 \mathrm{~min}$. in a lateral direction. The chloroplasts and endoplasm are pushed against the lateral side of the cell wall while striations on the cortex stay in situ. Width of the stalk: $140 \mu$ (Dark phase contrast).

Fig. 3b. The same stalk 4 hrs. after centrifugation showing restitution of the chloroplasts and other cell components. 
moving chloroplast trains from the stationary parallel tracks, i. e., from the striations affixed to the cortex. When they are detached locally from the cortex, or ectoplasm, they make projections into the vacuolar space and form temporary strands across the vacuole. Of the channels of flow on the cortex, there are also some which are forced to slide laterally alongside the inner surface of the ectoplasmic layer without being detached from it. When these strands slide, they can no longer keep the original orientation parallel to the cell axis, but are turned more and more obliquely crossing longitudinal striations on the cortex eventually taking a position nearly perpendicular to the cell axis.

The process of restitution of the cell contents accumulated onto the lateral side of the stalk is again instructive in getting insight into the mechanics of flow in this material. When an oblique strand is still present on the cortex, it is first resorbed to one of the parallel striations to which it is attached. When there are no oblique strands left, however, the restitutional movement of the cytoplasm and chloroplasts can no longer occur transversally across the striations but always along them either in acropetal or basipetal direction. Once a part of the endoplasm and chloroplasts reach one of the terminals of the stalk, they come back now along striations further apart from the centrifugal side. Repeating this process, it takes usually a few hours before a complete restitution of the cell contents is attained (Fig. 3b). Thus the cytoplasm takes by no means the shortest path for its restitution in this case. It can move in no other direction than the longitudinal one, or more exactly only along the striations.

\section{Isolation of the Protoplasm in vitro}

Attempt was made next to isolate the living cytoplasm from the cell and to observe its behavior. The negative pressure method isolating endoplasm from the Nitella internode $^{4)}$ is not applicable to this case, since, when the stalk is cut, the opening is soon closed with the coagulum of the cytoplasm and no spontaneous effusion takes place. This is a phenomenon which is not unusual in coenocytes. We therefore applied a means mentioned in the foregoing page. In case cytoplasmic drops with little visible vacuoles are needed, the stalk was centrifuged longitudinally prior to cutting it at the centrifugal end.

Cytoplasmic drops thus isolated, no matter whether they are vacuole-rich or vacuole-poor, usually survive a few days in vitro. They not only exhibit moderate amoeboid movement accompanied with changes in its contour, but often form hyalin protuberances or papillae. Similar phenomena have been observed and described also in other materials ${ }^{5,6}$. Here we shall pay our special attention to the movement of chloroplasts on a cytoplasmic strand which is occasionally formed between two drops connecting one with another. Chloroplasts attached to or mounted in the strand in a train appear to move "independently", each going with a speed different from another and sometimes even in opposite directions. It also happens that one chloroplast takes over another. Generally speaking, the movement of a single chloroplast is more or less jerky. Fig. 4 shows an example of extracellular cytoplasmic strands loaded with many chloroplasts where arrows show the directions and distances covered by the chloroplasts and some other visible particles during 5 seconds. The movement of the chloroplasts along these strands in vitro is extremely similar to that along transvacuolar strands formed temporarily with the cytoplasm detached from the cortex through centrifugation. It is also reminiscent of the movement of particles on trans- 


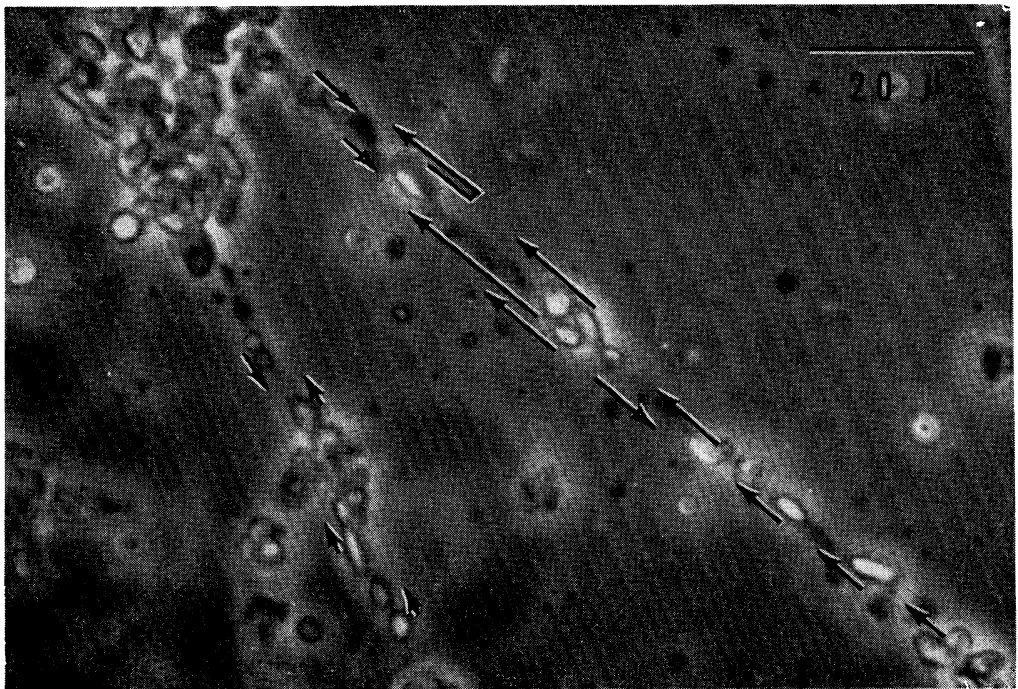

Fig. 4. Cytoplasmic strands formed in vitro in the natural cell sap. Chloroplasts move actively on the strands each with a speed of its own. The arrows show directions and distances covered by chloroplasts or some other particles within the same 5 second interval. (Analysis from a strip of cinémicrographic film).

vacuolar strands in parenchymatous cells exhibiting cytoplasmic movement of the circulation type.

As far as the authors' knowledge goes, such a cytoplasmic strand in vitro, along which chloroplasts move in one direction or the other, has not been reported before. This phenomenon is another evidence suggesting the presence of motile filaments as a structural component of the cytoplasmic strand, as will be discussed.

\section{Discussion}

In a typical rotation there is a stream of cytoplasm on one side of the cell and another stream directed to the opposite direction on the other side. These two channels of flow, whether wide or narrow, are actually a single channel, since the two are connected with one another at their ends to make a closed circulating belt along the cell wall.

So-called multistriate streaming, of which streaming in the sporangiophore of Phycomyces is another good example, is distinguished from " rotation" through multiplicity of the streaming channels. This is also to be distinguished from ordinary circulation by the stability of the streaming track and the higher regularity of a streaming pattern.

The above characterisitcs of the two types of streaming, rotational streaming and multistriate streaming, are naturally concerned with those on the visual level. An important question to be asked here is how far the basic mechanism is common in both. Though naturally a definite answer is still reserved for this question at present, it may be pointed out that the above observational facts are understandable, if we 
postulate for the multistriate streaming system in Acetabularia the presence of motile fibrils similar in their functional characteristics to those known in Nitella. Recently much has been learned about the behavior, function and ultrastructure of the motile fibrils through improved techniques of direct observation ${ }^{7-11)}$ and electron microscopy ${ }^{12}$. Though in Acetabularia, the motile fibrils as such, as any fibrillar structures which are supposed to be correlated with cytoplasmic motility have been found neither optically nor electron microscopically ${ }^{13,14}$ yet, it is expected that an essential part of the striations on the cortex along which endoplasm and chloroplasts stream in one direction or the other is composed of bundles of filaments possessed of the function producing counter-shifting force against the surrounding milieu. Since the striations are held to the cortex, the endoplasm in direct contact with them is supposed to move along them with the counter-shifting force in question.

In the case of the cytoplasmic strand in vitro, chloroplasts often move in opposite directions. This fact also suggests the presence of motile fibrils producing countershifting forces in opposite directions simultaneously in one and the same strand. This is probably true also of the transvacuolar strands so common in many plant cells.

In the light of our present knowledge, the most plausible explanation, if hypothetical, of the complicated streaming phenomena in Acetabularia will be made in terms of the motile cytoplasmic fibrils as a prime mover. Though it is still premature to make any constructive argument on the chemical basis of the multistriate streaming, it is interesting in this connection that Acetabularia cytoplasm was shown to have ATP sensitive proteins ${ }^{2}$. What we should like to stress in the present paper is the functional importance of the striations which are optically visualized on the cortex if the chloroplasts and the endoplasm in the sol state are removed through centrifugation.

The authors wish to express their appreciation to the staff of the Tamano Marine Biological Station of Okayama University for their help in collecting the material used for the present work.

\section{Summary}

A young stalk of Acetabularia exhibits cytoplasmic streaming of the so-called multistriate type before the cap is formed. Centrifuging the stalk either longitudinally or laterally, endoplasm and chloroplasts flowing in the form of many slender parallel channels are pushed aside, while many delicate gel striations running in parallel are left behind on the inner surface of the cortex (ectoplasmic layer). Multistriate cytoplasmic streaming takes place only alongside these striations. Centrifugemicroscope observation further reveals that slender channels of flow of the cytoplasm carrying chloroplasts in trains are detached by centrifugation from the striations more or less in unit strands. Similar strands are also formed in vitro between naked protoplasmic drops. The motile behavior of the chloroplasts is similar in both cases.

In order to explain multistriate streaming it is suggested that the motile fibrils functionally similar to those well studied in Nitella are present as a structural component responsible for protoplasmic movement in Acetabularia. 


\section{References}

1) Kamiya, N., Handb. d. Pflanzenphysiol. XVII/II, 979 (1962). 2) Takata, M., Ann. Rep. Sci. Works, Fac. Sci., Osaka Univ. 9: 63 (1961). 3) Sato, T., Bot. Mag. Tokyo $75: 394$ (1962). 4) Kamiya, N., and Kuroda, K., Proc. Japan Acad. $33: 149$ (1957). 5) Seifriz, W., Protoplasma $1: 1$ (1927). 6) Yotsuyanagi, Y., Cytologia 18: 202 (1953). 7) Jarosch, R., Phyton (Argentina) $6: 87$ (1956). 8)—, ibid. 15: 43 (1958). 9) Kamiya, N., Protoplasmatologia VIII/3/a, 1 (1959). 10) Kuroda, K., Primitive Motile Systems in Cell Biology, 31 (Allen, R. D., and Kamiya, N., Ed., Academic Press Inc., New York, 1964). 11) Kamitsubo, E., Proc. Japan Acad. 42 : 640 (1966). $\quad$ 12) Nagai, R., and Rabhun, L. I., J. Ultrastruc. Res. $14: 571$ (1966). 13) Bouck, G. B., Primitive Motile Systems in Cell Biology, 7 (Allen, R. D., and Kamiya, N., Ed., Academic Press Inc., New York, 1964). 14) Crawley, J. C. W., Exptl. Cell Res. 35: 497 (1964).

\section{摘要}

\section{神谷宣郎・黒田清子： カサノリの原形質流動に関する三三の観察}

ホソエガサ (Acetabularia calyculus) の若い主軸ではいわゆる多条型原形質流動がみられる. 本研究で は，このような材料を縦にまたは横に遠心処理した際に，流動原形質がどのように行動するかを遠心顕微鏡 下で連続的に追跡し，またその回復過程をしらべた．適度の遠心処理によって，流動原形質と葉緑体は細胞 の遠心端に集まるが，薄い外質層の内面に縦に平行に走るゲル状の細い線条は残る．流動は常にこれらの線

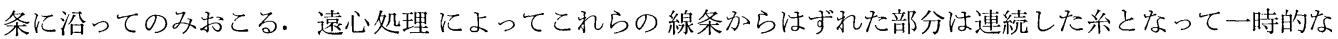
液胞横断原形質糸を形成する。これらの系は細胞外に遊離した原形質のつくる系と運動に関して同様な行 動をとる．車軸藻類の細胞でくわしく観察された運動性繊維に対忘すると思われる繊維構造は, まだカサノ リ類では見出されていないが，この場合にもとのような運動性繊維の存在を仅定することによって種々の観 察結果が理解される.（大阪大学理学部生物学教室） 